\title{
FARMACINĖ RŪPYBA ES IR LIETUVOJE
}

\author{
Jūratė Švarcaitė \\ Mpharm, MSc \\ Nacionalinè vaistų prekybos asociacija \\ Vienuolio g. 4-8, Vilnius, Lietuva \\ Elektroninis paštas jurate.svarcaite@nvpa.lt \\ Pateikta $2014 \mathrm{~m}$. sausio 15 d., parengta spausdinti $2014 \mathrm{~m}$. kovo $30 \mathrm{~d}$. \\ doi:10.13165/SPV-14-1-6-04
}

\section{Santrauka}

Farmaciné rüpyba - tai ịvairiapusé (pagal vaistininko kompetencija) paciento, kuriam paskirtas gydymas, priežiūra sudarant gydymo priežiüros plana ir siekiant optimalaus farmakologinio gydymo rezultato ir geresnès paciento gyvenimo kokybés. Lietuvoje farmacinè rūpyba turi büti igyvendinama nuo 2015 m. sausio 1 d., isigalejjus atitinkamam Geros vaistiniu praktikos nuostatu punktui. Daugumoje ES šaliu farmacinès rüpybos paslaugos pacientams jau teikiamos ne vienerius metus, yra aiškiai apibrežztos, reglamentuojamos ir apmokamos valstybès biudžeto lèšmis.

Šiame straipsnyje pristatoma farmacinès rüpybos koncepcija, farmacinès rüpybos paslaugos Europos vaistinèse, aprašomos pagal 4 pagrindines vaistininko profesinès veiklos sritis:

- vaistu kokybé, saugumas ir prieinamumo užtikrinimas,

- pacientu gydymo rezultatu gerinimas ir optimizavimas,

- visuomenés sveikatos gerinimas,

- sveikatos sistemos efektyvumo didinimas.

Igyvendinant farmacinę rūpyba Lietuvoje, remiantis kitu šalių pavyzdžiu svarbu apibrěžti farmacinés rüpybos sąvoką, nustatyti farmacinés rüpybos teikimo tvarką ir ịvardinti farmacinès rüpybos paslaugas, kurias gali teikti reikiamos kvalifikacijos vaistininkai, nustatyti farmacijos specialistu profesinés kvalifikacijos kèlimo taisykles.

Reikšminiai žodžiai: farmacinè rūpyba, vaistinè, farmacijos specialistas, pirminè sveikatos priežiūra, Europos Sajunga, farmacinè paslauga.

\section{Ivadas}

Hepleris ir Strandas (JAV) 1975 m. farmacinę rūpybą apibrěžè kaip „pacientui suteiktą rūpybą, užtikrinant saugų ir racionalų vaistų vartojimą". Farmacinès rūpybos (angl. Pharmaceutical care) terminas skirtingomis kalbomis kalbančiose ES šalyse verčiamas skirtingai ${ }^{1}$, net ta pačia kalba kalbančiose šalyse (pvz., Nyderlandai ir Belgija) jis gali skirtis.

1 Van Mil and Schulz: a Review of Pharmaceutical care. 2006, 7(1): 155 [interaktyvus]. [žiūrèta 2013-19-

13]. <http://hhpronline.org/wp-content/uploads/2012/05/van_Mil_and_Schulz.pdf>. 
Nepaisant lingvistinių skirtumų, farmacinè rūpybos koncepcija pasaulinèje vaistininko praktikoje yra išsamiai aprašyta, aiškiai apibrèžta ir apima įvairiapusę (kiek leidžiama pagal vaistininko kompetenciją ir nacionalinę teisę) paciento, kuriam paskirtas farmakologinis gydymas, priežiūrą sudarant gydymo priežiūros planą ir siekiant optimalaus farmakologinio gydymo rezultato ir geresnès paciento gyvenimo kokybès.

Farmacinès rūpybos koncepcijos formavimas ir igyvendinimas nulèmè ir šiuolaikinę vaistininko kompetencijų raidą: senosiose ES šalyse, JAV, Australijoje vaistininko profesinè veikla senokai peržengè tradicinį vaistų paruošimą, analizę, išdavimą ir informacijos apie vaistus suteikimą ${ }^{2}$. Išplèstas minimalus vaistininko profesinės veiklos sąrašas, apibrèžtas atnaujintoje Europos Sąjungos profesinių kvalifikacijų pripažinimo direktyvoje (A70038/2013 ), geriausiai atspindi vaistininkų profesinès veiklos evoliuciją Europos Sąjungos šalyse. Šis minimalios ES vaistininko profesinès veiklos sąrašas papildytas trimis naujomis vaistininko veiklos sritimis, t. y.:

- pranešimas apie nepageidaujamos reakcijos ị farmacijos produktus atvejus kompetentingoms institucijoms;

- individuali pagalba pacientams, kuriems paskirtas gydymas vaistais;

- pagalba rengiant vietines ir nacionalines visuomenès sveikatos kampanijas.

Apibrèžta, kad „individuali vaistininko pagalba pacientams, kuriems paskirtas gydymas vaistais" - tai pirmasis oficialus farmacinès rūpybos koncepcijos pripažinimas Europos Sąjungos teisèje. Iki tol buvusi daugiau profesinè iniciatyva, farmacinè rūpyba šiuo teisès aktu pripažinta kertine vaistininko kompetencija visoje ES.

LR sveikatos apsaugos ministro 2007 m. birželio 15 d. įsakymu Nr. V-494 (Žin., 2007, Nr. 68-2690) patvirtintuose Geros vaistinių praktikos nuostatuose (2 p.) reglamentuota, jog geros vaistinių praktikos tikslas - užtikrinti gyventojų ir visos visuomenès sveikatą; šiam tikslui igyvendinti, be kita ko, būtina suteikti gyventojams kokybišką farmacinę paslaugą ir, vaistinei pasirengus, vykdyti farmacinę rūpybą. Geros vaistinių praktikos nuostatų dalis, apibrèžianti farmacinès rūpybos paslaugų teikimą, Lietuvoje turètų ísigalioti nuo $2015 \mathrm{~m}$. sausio $1 \mathrm{~d}$., tačiau farmacinès rūpybos esmè nacionaliniame teisiniame reguliavime nèra detaliai atskleista ir tèra tik teorinè sąvoka, be to, šiuose nuostatuose minèta sąvoka savo esme nesiskiria nuo farmacinès paslaugos sąvokos, apibrèžtos Farmacijos įstatyme. Taigi LR teisiniame reguliavime šiuolaikinè farmacinè rūpyba nèra įtvirtinta.

2 From making medicines to optimising outcomes: The evolution of a profession 1912-2012 [interaktyvus]. [žiūrèta 2013-19-13]. <http://www.fip.org/centennial/files/static/UCL_BOOKLET_Web.pdf>.

3 <http://www.europarl.europa.eu/sides/getDoc.do?pubRef=-//EP//TEXT+TA+P7-TA-2013$0408+0+\mathrm{DOC}+\mathrm{XML}+\mathrm{V} 0 / / \mathrm{EN}$ language $=\mathrm{EN}>$. 
1 lentelè. Farmacinès paslaugos, teikiamos visuomenès vaistinėse Europos Sąjungos šalyse*

\begin{tabular}{|c|c|c|c|c|c|c|c|c|c|c|c|c|c|c|c|c|c|c|}
\hline ŠALIS & 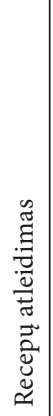 & 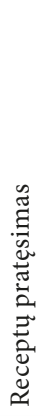 & 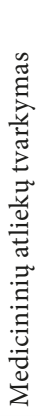 & 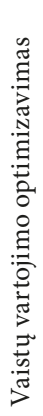 & 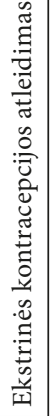 & 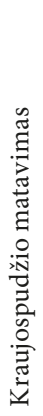 & 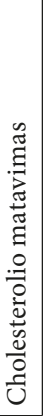 & 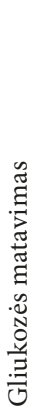 & 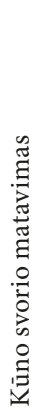 & 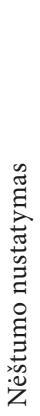 & 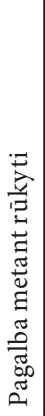 & 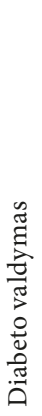 & 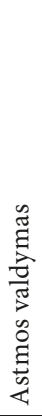 & 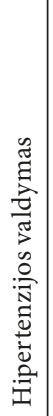 & 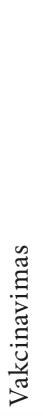 & 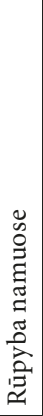 & 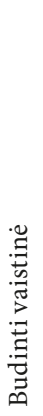 & $\stackrel{\star \pi}{\stackrel{*}{*}}$ \\
\hline Austrija & $\mathrm{T}$ & $\mathrm{N}$ & $\mathrm{T}$ & $\mathrm{N}$ & $\mathrm{T}$ & $\mathrm{T}$ & $\mathrm{T}$ & $\mathrm{T}$ & $\mathrm{T}$ & $\mathrm{T}$ & $\mathrm{T}$ & $\mathrm{T}$ & $\mathrm{T}$ & $\mathrm{T}$ & $\mathrm{N}$ & $\mathrm{T}$ & $\mathrm{T}$ & 1 \\
\hline Belgija & $\mathrm{T}$ & $\mathrm{T}$ & $\mathrm{T}$ & $\mathrm{N}$ & $\mathrm{T}$ & $\mathrm{N}$ & $\mathrm{N}$ & $\mathrm{N}$ & $\mathrm{N}$ & $\mathrm{N}$ & $\mathrm{T}$ & $\mathrm{N}$ & $\mathrm{N}$ & $\mathrm{N}$ & $\mathrm{N}$ & $\mathrm{T}$ & $\mathrm{T}$ & 1 \\
\hline Kroatija & $\mathrm{T}$ & $\mathrm{T}$ & $\mathrm{T}$ & $\mathrm{N}$ & $\mathrm{N}$ & $\mathrm{T}$ & $\mathrm{N}$ & $\mathrm{N}$ & $\mathrm{T}$ & $\mathrm{T}$ & $\mathrm{N}$ & $\mathrm{N}$ & $\mathrm{N}$ & $\mathrm{N}$ & $\mathrm{N}$ & $\mathrm{N}$ & $\mathrm{T}$ & 1 \\
\hline Danija & $\mathrm{T}$ & $\mathrm{N}$ & $\mathrm{T}$ & $\mathrm{T}$ & $\mathrm{T}$ & $\mathrm{T}$ & $\mathrm{T}$ & $\mathrm{T}$ & $\mathrm{T}$ & $\mathrm{N}$ & $\mathrm{T}$ & $\mathrm{N}$ & $\mathrm{T}$ & $\mathrm{N}$ & $\mathrm{N}$ & $\mathrm{T}$ & $\mathrm{T}$ & 1 \\
\hline Estija & $\mathrm{T}$ & $\mathrm{N}$ & $\mathrm{T}$ & $\mathrm{T}$ & $\mathrm{N}$ & $\mathrm{N}$ & $\mathrm{N}$ & $\mathrm{N}$ & $\mathrm{N}$ & $\mathrm{N}$ & $\mathrm{N}$ & $\mathrm{N}$ & $\mathrm{N}$ & $\mathrm{N}$ & $\mathrm{N}$ & $\mathrm{N}$ & $\mathrm{T}$ & 1 \\
\hline Suomija & $\mathrm{T}$ & $\mathrm{T}$ & $\mathrm{T}$ & $\mathrm{T}$ & $\mathrm{T}$ & $\mathrm{T}$ & $\mathrm{T}$ & $\mathrm{T}$ & $\mathrm{T}$ & $\mathrm{N}$ & $\mathrm{T}$ & $\mathrm{T}$ & $\mathrm{T}$ & $\mathrm{T}$ & $\mathrm{N}$ & $\mathrm{N}$ & $\mathrm{T}$ & $\mathrm{T}$ \\
\hline Prancūzija & $\mathrm{T}$ & $\mathrm{T}$ & $\mathrm{T}$ & $\mathrm{T}$ & $\mathrm{T}$ & $\mathrm{N}$ & $\mathrm{N}$ & $\mathrm{N}$ & $\mathrm{T}$ & $\mathrm{T}$ & $\mathrm{T}$ & $\mathrm{T}$ & $\mathrm{T}$ & $\mathrm{T}$ & $\mathrm{N}$ & $\mathrm{T}$ & $\mathrm{T}$ & 1 \\
\hline Vokietija & $\mathrm{T}$ & $\mathrm{N}$ & $\mathrm{T}$ & $\mathrm{T}$ & $\mathrm{T}$ & $\mathrm{T}$ & $\mathrm{T}$ & $\mathrm{T}$ & $\mathrm{T}$ & $\mathrm{T}$ & $\mathrm{T}$ & $\mathrm{T}$ & $\mathrm{T}$ & $\mathrm{T}$ & $\mathrm{N}$ & $\mathrm{T}$ & $\mathrm{T}$ & 1 \\
\hline Airija & $\mathrm{T}$ & $\mathrm{N}$ & $\mathrm{T}$ & $\mathrm{N}$ & $\mathrm{T}$ & $\mathrm{T}$ & $\mathrm{T}$ & $\mathrm{T}$ & $\mathrm{T}$ & $\mathrm{T}$ & $\mathrm{T}$ & $\mathrm{N}$ & $\mathrm{N}$ & $\mathrm{N}$ & $\mathrm{T}$ & $\mathrm{N}$ & $\mathrm{N}$ & $\mathrm{T}$ \\
\hline Italija & $\mathrm{T}$ & $\mathrm{T}$ & $\mathrm{T}$ & $\mathrm{N}$ & $\mathrm{T}$ & $\mathrm{T}$ & $\mathrm{T}$ & $\mathrm{T}$ & $\mathrm{T}$ & $\mathrm{T}$ & $\mathrm{T}$ & $\mathrm{T}$ & $\mathrm{T}$ & $\mathrm{T}$ & $\mathrm{N}$ & $\mathrm{T}$ & $\mathrm{T}$ & 1 \\
\hline Makedonija & $\mathrm{T}$ & $\mathrm{T}$ & $\mathrm{T}$ & $\mathrm{N}$ & $\mathrm{T}$ & $\mathrm{T}$ & $\mathrm{T}$ & $\mathrm{T}$ & $\mathrm{T}$ & $\mathrm{T}$ & $\mathrm{N}$ & $\mathrm{N}$ & $\mathrm{N}$ & $\mathrm{N}$ & $\mathrm{N}$ & $\mathrm{N}$ & $\mathrm{T}$ & 1 \\
\hline Nyderlandai & $\mathrm{T}$ & $\mathrm{T}$ & $\mathrm{T}$ & $\mathrm{T}$ & $\mathrm{T}$ & $\mathrm{T}$ & $\mathrm{T}$ & $\mathrm{T}$ & $\mathrm{T}$ & $\mathrm{T}$ & $\mathrm{T}$ & $\mathrm{T}$ & $\mathrm{T}$ & $\mathrm{T}$ & $\mathrm{T}$ & $\mathrm{T}$ & $\mathrm{T}$ & $\mathrm{T}$ \\
\hline Norvegija & $\mathrm{T}$ & $\mathrm{T}$ & $\mathrm{T}$ & $\mathrm{T}$ & $\mathrm{N}$ & $\mathrm{T}$ & $\mathrm{N}$ & $\mathrm{T}$ & $\mathrm{N}$ & $\mathrm{N}$ & $\mathrm{T}$ & $\mathrm{N}$ & $\mathrm{T}$ & $\mathrm{N}$ & $\mathrm{N}$ & $\mathrm{N}$ & $\mathrm{N}$ & $\mathrm{T}$ \\
\hline Lenkija & $\mathrm{T}$ & $\mathrm{N}$ & $\mathrm{T}$ & $\mathrm{N}$ & $\mathrm{N}$ & $\mathrm{T}$ & $\mathrm{N}$ & $\mathrm{N}$ & $\mathrm{T}$ & $\mathrm{N}$ & $\mathrm{T}$ & $\mathrm{T}$ & $\mathrm{T}$ & $\mathrm{T}$ & $\mathrm{N}$ & $\mathrm{N}$ & $\mathrm{T}$ & 1 \\
\hline Portugalija & $\mathrm{T}$ & $\mathrm{T}$ & $\mathrm{T}$ & $\mathrm{T}$ & $\mathrm{T}$ & $\mathrm{T}$ & $\mathrm{T}$ & $\mathrm{T}$ & $\mathrm{T}$ & $\mathrm{T}$ & $\mathrm{T}$ & $\mathrm{T}$ & $\mathrm{T}$ & $\mathrm{T}$ & $\mathrm{T}$ & $\mathrm{T}$ & $\mathrm{T}$ & 1 \\
\hline Slovakija & $\mathrm{T}$ & $\mathrm{N}$ & $\mathrm{T}$ & $\mathrm{T}$ & $\mathrm{T}$ & $\mathrm{T}$ & $\mathrm{T}$ & $\mathrm{T}$ & $\mathrm{T}$ & $\mathrm{N}$ & $\mathrm{N}$ & $\mathrm{T}$ & $\mathrm{T}$ & $\mathrm{N}$ & $\mathrm{N}$ & $\mathrm{N}$ & $\mathrm{T}$ & 1 \\
\hline Slovėnija & $\mathrm{T}$ & $\mathrm{T}$ & $\mathrm{T}$ & $\mathrm{T}$ & $\mathrm{N}$ & $\mathrm{T}$ & $\mathrm{T}$ & $\mathrm{T}$ & $\mathrm{T}$ & $\mathrm{N}$ & $\mathrm{N}$ & $\mathrm{T}$ & $\mathrm{N}$ & $\mathrm{T}$ & $\mathrm{N}$ & $\mathrm{N}$ & $\mathrm{T}$ & 1 \\
\hline Ispanija & $\mathrm{T}$ & $\mathrm{T}$ & $\mathrm{T}$ & $\mathrm{T}$ & $\mathrm{T}$ & $\mathrm{T}$ & $\mathrm{T}$ & $\mathrm{T}$ & $\mathrm{T}$ & $\mathrm{T}$ & $\mathrm{T}$ & $\mathrm{T}$ & $\mathrm{T}$ & $\mathrm{T}$ & $\mathrm{N}$ & $\mathrm{T}$ & $\mathrm{T}$ & $\mathrm{T}^{1}$ \\
\hline Švedija & $\mathrm{T}$ & $\mathrm{N}$ & $\mathrm{T}$ & $\mathrm{T}$ & $\mathrm{T}$ & $\mathrm{T}$ & $\mathrm{T}$ & $\mathrm{T}$ & $\mathrm{T}$ & $\mathrm{T}$ & $\mathrm{T}$ & $\mathrm{T}$ & $\mathrm{T}$ & $\mathrm{T}$ & $\mathrm{T}$ & $\mathrm{N}$ & $\mathrm{T}$ & 1 \\
\hline Šveicarija & $\mathrm{T}$ & $\mathrm{T}$ & $\mathrm{T}$ & $\mathrm{T}$ & $\mathrm{T}$ & $\mathrm{T}$ & $\mathrm{T}$ & $\mathrm{T}$ & $\mathrm{T}$ & $\mathrm{T}$ & $\mathrm{T}$ & $\mathrm{T}$ & $\mathrm{T}$ & $\mathrm{T}$ & $\mathrm{N}$ & $\mathrm{N}$ & $\mathrm{T}$ & 1 \\
\hline Turkija & $\mathrm{T}$ & $\mathrm{N}$ & $\mathrm{T}$ & $\mathrm{T}$ & $\mathrm{T}$ & $\mathrm{T}$ & $\mathrm{N}$ & $\mathrm{T}$ & $\mathrm{T}$ & $\mathrm{T}$ & $\mathrm{N}$ & $\mathrm{N}$ & $\mathrm{N}$ & $\mathrm{T}$ & $\mathrm{N}$ & $\mathrm{N}$ & $\mathrm{T}$ & 1 \\
\hline $\begin{array}{l}\text { Jungtinè } \\
\text { Karalystė }\end{array}$ & $\mathrm{T}$ & $\mathrm{T}$ & $\mathrm{T}$ & $\mathrm{T}$ & $\mathrm{T}$ & $\mathrm{T}$ & $\mathrm{T}$ & $\mathrm{T}$ & $\mathrm{T}$ & $\mathrm{T}$ & $\mathrm{T}$ & I & I & I & $\mathrm{T}$ & $\mathrm{T}$ & $\mathrm{T}$ & I \\
\hline
\end{tabular}

ŽIV nustatymas, metadono pakaitinè terapija, adatų keitimas, sveikatinimo programos, sveikatos informacija, ansktyva ligų detekcija ir kt.

*Farmacinés grupés prie Europos Sąjungos 2011-2012 metų duomenų bazė

Farmacinès rūpybos paslaugų, teikiamų Europos Sąjungos šalių vaistinėse, apžvalga

Farmacinė rūpyba kitose ES šalyse iggyvendinta diegiant ịvairias farmacinès rūpybos paslaugas, iš kurių geriausiai apibrèžta ir reglamentuota - lètinèmis ligomis sergančių pacientų priežiūra, t. y. diabeto, hipertenzijos, astmos ir kitų ligų gydymo priežiūra sudarant individualų paciento gydymo planą ir pagalba jo laikantis. Taip pat vaistininkai gali pratęsti pa- 
cientų, vartojančių vaistus lètinėms ligoms gydyti, receptus, atlikti ir vertinti biocheminius tyrimus, skiepyti, dalyvauti prevencinèse programose ir t. t. (1 lentelè).

Farmacinès rūpybos paslaugos tradiciškai teikiamos pagal specialias vaistinès veiklos procedūras reikiamą kvalifikaciją igijusių vaistininkų. Farmacinès rūpybos paslaugas teikiančioms vaistinėms keliami reikalavimai priklauso nuo teikiamų farmacinès rūpybos paslaugų kompleksiškumo. Europos vaistinèse vaistininkų teikiamas farmacinès rūpybos paslaugas patogu apžvelgti pagal keturias pagrindines vaistininko veiklos sritis.

\section{Vaistų kokybės, saugumo ir prieinamumo užtikrinimas}

Kad pacientas tinkamu laiku gautų tinkamą, kokybišką ir saugų vaistą, yra vaistininko praktikos kertinis akmuo. Ši vaistininko veiklos sritis yra išplèsta igyvendinant paslaugas, tokias kaip:

- Ekstrinis receptiniu vaistu be recepto išdavimas ir receptu pratęsimas

Jungtinejje Karalysteje, Belgijoje, Kroatijoje ir kt. vaistininkas gali pratęsti kompensuojamųjų vaistų receptus, kai ligos eiga yra stabili ir tinkamai kontroliuojama. Tai padeda mažinti eiles pas šeimos gydytojus, jie daugiau laiko gali skirti rimtų ligų gydymui ir pacientų, kurių ligos eiga nestabili, priežiūrai. Tai taip pat pagerina vaistų ir sveikatos paslaugų prieinamumą pacientams. Tokios paslaugos pavyzdys galètų būti, hipertonine liga sergančio paciento, kuriam yra paskirtas gydymas vaistais, kuris nesikeičia daugiau nei vienus metus, priežiūra. Tokiu atveju, ịvertinęs ligonio būklę apklausos metu ir pamatavęs kraujo spaudimą, vaistininkas gali pratęsti receptus nustatytam laikotarpiui, informuodamas gydanti šeimos gydytoją.

Be to, Jungtineje Karalysteje ir Airijoje skubiais atvejais, pvz., kai pasibaigia lètinès ligos vaistai, o gydytojas nedirba ar atostogauja arba pacientas atostogaudamas pamiršta savo vaistus, vaistininkai be gydytojo recepto gali išduoti receptinius vaistus. Taip išvengiama atvejų, kai pacientai yra priversti nutraukti gydymą dẻl to, kad pamiršo laiku užsirašyti pas gydytoją ar gydytojo paskirtas kito apsilankymo laikas yra vèliau nei baigiasi vaisto atsargos. Vaistininkas tokiu atveju gali išduoti vaisto kiekį, kurio pacientui užtektų iki gydytojo paskirto kito susitikimo. Tokiu būdu išvengiama gydymo (šiuo atveju negydymo) komplikacijų, galimų hospitalizavimo atvejų ir pagerinamas vaistų ir sveikatos priežiūros paslaugų prieinamumas gyventojams.

\section{- Individualiu vaisto dozių paruošimas ir išdavimas}

Pacientams, kurių gydymo planai ypač sudètingi ar kenčiantiems nuo dimensijos ar kitų neurologinių susirgimų, Jungtinès Karalystès, Ispanijos, Švedijos ir kt. ${ }^{4}$ vaistinèse siūloma individualizuota vaisto dozių paruošimo paslauga. Šios paslaugos esmė yra originalių vaistų pakuočių atidarymas, išardymas ir perpakavimas ị vienkartinių dozių sistemą. Sistemoje vaistai yra sugrupuoti pagal jų vartojimo laiką ir dieną. Tokios pakuotès gali būti savaitès, 28 dienų ar skirtos ilgesniam gydymo laikotarpiui. Tai racionalizuoja vaistų vartojimą, yra patogu pacientui: pagerina vaistų vartojimą ir padeda laikytis gydymo plano, nepraleidžiant paskirtų vaisto dozių. Tokia paslauga taip pat teikiama slaugos skyriuose ir senjorų priežiūros įstaigose, kur nèra vaistininko etato ir kitaip nėra galimybės prižiūrèti racionalų ir tinkamą vaistų vartojimą.

Automated dose dispensing service for primary healthcare patients: a systematic review. Sinnemäki, Juha, et al. Systematic Reviews 2013, 2: 1 doi:10.1186/2046-4053-2-1 [interaktyvus]. [žiūrèta 2013-1913]. <http://www.systematicreviewsjournal.com/content/2/1/1>. 


\section{Pacientų gydymo rezultatų gerinimas ir optimizavimas}

Vaistininko suteikiamos farmacinès rūpybos esmè yra užtikrinti maksimalius gydymo rezultatus ir sumažinti pašalinio poveikio riziką per vaistų parinkimą, derinimą ir vartojimą. Tai galima pasiekti tokiomis paslaugomis kaip:

- Paciento vartojamy vaisty optimizacija

Geriausias to pavyzdys yra vaistininko atliekama paciento vaistų vartojimo peržiūra. Tai farmacinès rūpybos paslauga, suteikiama individualios konsultacijos metu, kai identifikuojami visi paciento vartojami vaistai, maisto papildai ir kitos sveikatinimosi priemonès, aptariamas ju veikimas, vartojimas ir identifikuojamos visos galimos ir esamos problemos, susijusios su vaistų vartojimu, ir sąveikos. Ši paslauga pagerina paciento žinias apie jo ligą(-as) ir vartojamus vaistus, racionalizuoja vaistų vartojimą, identifikuojamos vaistų sąveikos, šalutiniai poveikiai, mažinamos farmacinès atliekos ir kita. Identifikuotos problemos aptariamos su pacientu ir / arba gali būti susisiekta su gydančiu gydytoju. Jungtinèje Karalystejje ši paslauga ${ }^{5}$ rekomenduojama pacientams, vartojantiems daugiau nei vieną vaistą ir sergantiems rizikos grupei priskirtomis lètinèmis ligomis, neseniai iš ligoninès išrašytiems pacientams, ir yra apmokama valstybès. Vaistų vartojimo suderinimo ir sekimo paslauga, teikiama Ispanijos vaistinèse, veikia panašiu principu. Čia rizikos grupès pacientai monitoruojami periodiškai. Švedijoje vykdyto vaistų vartojimo optimizavimo programos efektyvumo tyrimo rezultatai parodè, kad vidutiniškai paciento vartojamų vaistų kiekis sumažejo nuo 12,4 iki 10,7. Paciento metinis biudžetas vaistams sumažejo 1448 švediškomis kronomis (t. y. apytikriai 552 litais) ${ }^{6}$.

- Lètiniu ligù valdymas

Pacientai, sergantys lètinèmis ligomis, vaistinejje lankosi dažniau nei kitose sveikatos priežiūros ịstaigose. Astma, cukriniu diabetu ar hipertenzija sergantys pacientai lankosi vaistinejje taip pat dažnai ar net dažniau nei pas savo bendrosios praktikos gydytoją. Dèl to diegiant lètinių ligų valdymo programas atsiranda unikali galimybė anksti nustatyti neigiamus pakitimus ar padidejusią riziką, padèti pacientams geriau rūpintis savimi, gerinti gydymo rezultatus. Lètinių ligų valdymo programos vaistinejeje padeda pacientams geriau pažinti savo ligą, sekti jos eigą, keisti gyvenseną, tinkamai vartoti paskirtus vaistus, padeda pasiekti geresnę gydymo kokybę, sumažina sveikatos sistemos kaštus dèl sumažèjusių gydymo išlaidų, išvengtų ar anksti identifikuotų komplikacijų ir kita.

- Nesunkiu susirgimu gydymas

Žmonès į vaistininkus dažnai kreipiasi skųsdamiesi įvairiais negalavimais ir susirgimais. Dažniausi negalavimai, dèl kurių kreipiamasi, yra peršalimo ligos, virškinimo negalavimai, konjunktyvitas, alergijos, skausmas.

Dalis vaistų, kurie padètų efektyviai spręsti šias problemas, yra receptiniai. Tai riboja vaistininko galimybes padeti pacientui, kuris turi gaišti laiką eilèse pas šeimos gydytoją, kad būtų paskirtas receptinis vaistas. Jungtinejje Karalystėje, Šveicarijoje vaistininkas gali parduoti tam tikrus receptinius vaistus pagal numatytas indikacijas ${ }^{8}$, t. y. numatyta galimybe nesunkių susirgimų atveju suteikti efektyvią pagalbą vaistinèse.

<http://www.mhra.gov.uk/home/groups/pl-a/documents/websiteresources/con2023072.pdf>

Jonsson, J.; Renberg-Lindholm, E.; Ohlen, K.; Hjertsen, E. Drug utilization reviews by a pharmacist of elderly people living at home - an open trial in two Primary Health Care Centres in Sweden. Presented at the World Congress of Pharmacy and Pharmaceutical Sciences. September 2007. Beijing

7 PGEU Policy Statement: Targeting adherence: Improving patient outcomes in Europe Through Community Pharmacist's Intervention 2008 [interaktyvus]. [žiūrèta 2013-19-13]. <http://www.pgeu.eu/en/ policy/5-adherence.html>.

8 <http://www.nhs.uk/Livewell/Pharmacy/Pages/Commonconditions.aspx >. 


\section{Visuomenès sveikatos gerinimas}

Vaistininko kaip visuomenès sveikatos specialisto misija nesibaigia racionaliu vaistų vartojimu. Stengiantis išnaudoti ši potencialą vaistininkai ir vaistinės daugelyje šalių tampa platesnès visuomenès sveikatos strategijos dalimi:

- Prevencija ir ankstyva ligų diagnozé

Vaistinèse dažnai lankosi žmonès, kurie aplenkia visas kitas gydymo priežiūros ịstaigas. Tai yra unikali galimybė žmonėms pasitikrinti sveikatą ir įvertinti savo rizikas. Tai leidžia anksčiau identifikuoti tam tikras ligas ir nusiuntus šiuos pacientus pas gydytoją patvirtinti diagnozę ir anksti imtis tikslinio gydymo, taip užkertant kelią ligos įsisenejjimui. Taip pat asmenims, kurie dar neserga, tačiau padidejjusi rizika susirgti, rekomenduojama sveika gyvensena ar kitos priemonès, nereikalaujančios farmakoterapinio gydymo. Tokios programos ${ }^{9}{ }^{10},{ }^{11}$ apima metabolinių parametrų, tokių kaip gliukozės, cholesterolio kiekio kraujyje, kaulų tankio, kraujospūdžio matavimą, fizinio aktyvumo, mitybos ịpročių îvertinimą ir yra teikiamos daugelyje Europos Sąjungos šalių.

- Vakcinacija

Pagal Europos Tarybos 2009 metų rekomendacijas ${ }^{12}$ ES šalys narès iki 2014-2015 m. žiemos sezono turètų pasiekti PSO rekomenduojamą 75 \% rizikos grupejje esančių žmonių skiepijimo mastą. Atsižvelgiant ị Europos ligų prevencijos ir kontrolès centro (ECDC) paskelbtas gaires, šis 75 \% tikslas turètų būti taikomas asmenims, vyresniems kaip 65 metų, lètinių sveikatos sutrikimų turintiems žmonems, néščiosioms ir vaikams. Dauguma ES šalių (išskyrus Nyderlandus) nuo šių rodiklių vis dar atsilieka. Lietuvoje 2010-2011 m. pasiskiepijo 7 proc. šalies gyventojų, apie $18 \%$ iš jų vyresnio amžiaus ${ }^{13}$. Siekiant efektyviai spręsti šią problemą, kai kuriose ES šalyse yra sudarytos sąlygos atitinkamos kvalifikacijos farmacijos specialistams administruoti vakcinas vaistinėse. Ši praktika yra plačiai paplitusi JAV, Portugalijoje, D. Britanijoje, Airijoje ir šiuo metu diegiama Slovakijoje. Kaip rodo atlikti tyrimai Airijoje, 22 \% žmonių, besiskiepijančių vaistinèje, tai daro pirmą $\operatorname{kartą~}^{14}$. Be gripo vakcinų, vaistinèse galima pasiskiepyti nuo erkinio encefalito, plaučių uždegimo sukèlèjo, tropinių ligų sukèlèjų, herpes zooster.

- Pagalba metantiems rūkyti

Pagalba metantiems rūkyti yra pripažinta ir efektyvi farmacinè paslauga ${ }^{15},{ }_{16}^{16}$. Vaistininkas gali padèti sèkmingai mesti rūkyti dèl savo išskirtinès padèties sveikatos sistemos grandinèje, farmakologijos žinių, kurios gali padeti metančiajam rūkyti išsirinkti tinkamiausią nerecep-

$9<$ http://europharm.netapotek.dk/file/14947>.

$10<$ http://www.cespharm.fr/en/Prevention-sante/Health-education/The-pharmacist-s-role $>$.

11 Pharmacy-based Metabolic Syndrome Management Programme developed by the Hungarian National Pharmaceutical Care Committee and supported by EuroPharm Forum [interaktyvus]. [žiūrèta 2013-19-13]. <http://europharm.pbworks.com/w/page/19341650/Metabolic\%20Syndrome>.

12 Tarybos 2009/1019/ES ES rekomendacija dèl skiepijimo nuo sezoninio gripo [interaktyvus]. [žiūrèta 2013-19-13]. <http://eur-lex.europa.eu/LexUriServ/LexUriServ.do?uri=OJ:L:2009:348:0071:0072:LT:PDF>.

13 < http://www.selonija.lt/2013/01/07/sergamumas-gripu-ir-vakcinacija-nuo-gripo/>.

14 Irish Pharmacy Union statistics 2012.

15 Results of a smoking cessation clinic in community pharmacy practice. Kennedy DT, Giles JT, Chang ZG, Small RE, Edwards JH. J Am Pharm Assoc (Wash). 2002, Jan-Feb, 42(1): 51-56.

16 Community pharmacists involvement in smoking cessation: familiarity and implementation of the National smoking cessation guideline in Finland Terhi Kurko, Kari Linden, Kirsi Pietilä, Patrick Sandström, Marja Airaksinen. BMC Public Health 2010, 10: 444 [interaktyvus]. [žiūrèta 2013-19-13]. $<$ http://www.biomedcentral.com/1471-2458/10/444>. 
tinį nikotino pakaitalą ar kitą tinkamą preparatą. Pokalbis apie rūkymo žalą ir pasiruošimo mesti rūkyti įvertinimas rekomenduojamas visų vaistininko konsultacijų metu. Efektyvios pagalbos metantiems rūkyti programos susideda iš tikslingos pasiruošimo mesti rūkyti konsultacijos, individualaus metimo rūkyti plano sudarymo ir pakartotinių konsultacijų.

\section{Sveikatos sistemos efektyvumo didinimas}

Minètos paslaugos daugelyje šalių yra apmokamos valstybės, privataus draudimo ir / arba paciento lěšomis. Farmacinè rūpyba leidžia ${ }^{17}$ sumažinti darbo krūvị pirminèje sveikatos priežiūros grandyje ir igalina farmakologinio gydymo efektyvumo stebėseną, taip pat anksti identifikuoti pacientus, turinčius su vaistų vartojimu susijusių problemų ar dar nediagnozuotų kitų sveikatos problemų. Didejja bendrosios praktikos gydytojų darbo efektyvumas, jie gali daugiau laiko skirti ūmių susirgimų ir komplikuotų pacientų gydymui, mažèja jų bendras užimtumas. Pacientai geriau prižiūrimi: su vaistų vartojimu susijusios problemos pastebimos anksčiau, mažèja nedarbingų dienų, ligoninejje praleistų dienų skaičius, gerèja pacientų gyvenimo kokybė ir trukmè. Lètinès ligos diagnozuojamos anksčiau, atsiranda galimybè anksčiau paskirti tinkamą gydymą.

\section{Išvados ir pasiūlymai}

1. Igyvendinant farmacinę rūpybą Lietuvoje, remiantis kitų šalių pavyzdžiu svarbu apibrèžti farmacinès rūpybos sąvoką, nustatyti farmacinès rūpybos teikimo tvarką ir įvardinti farmacinès rūpybos paslaugas, kurias gali teikti reikiamos kvalifikacijos vaistininkai, nustatyti farmacijos specialistų profesinès kvalifikacijos kèlimo taisykles.

2. Nors Geros vaistinių praktikos nuostatuose bandyta apibrèžti farmacinès rūpybos sąvoką, pagal Sveikatos sistemos ịstatymo 3 straipsnị (Sveikatos santykių teisinio reguliavimo ribos), tik ịstatymai nustato farmacinès veiklos subjektų teises ir pareigas farmacinèje veikloje, sveikatinimo veiklos organizavimo pagrindus, todèl manytina, kad farmacinès rūpybos sąvoką ir pagrindus pirmiausia būtina ịtvirtinti įstatymu. Kadangi tai pirmiausia susiję su vaistininkų teisėmis ir pareigomis, tokias nuostatas tikslingiausia įtraukti ị Farmacijos ìstatymą, kartu keičiant ir priimant poįstatyminius aktus (SAM įsakymą), detalizuojančius farmacinès rūpybos paslaugų teikimo tvarką.

\section{Literatūra}

1. Developing Pharmacy Practice. A focus on Patient Care. Handbook 2006 edition. WHO and FIP [interaktyvus]. [žiūrèta 2013-19-13]. <http://www.fip.org/files/fip/publications/ DevelopingPharmacyPractice/DevelopingPharmacyPracticeEN.pdf $>$.

2. Health at a Glance: Europe 2012. OECD Report [interaktyvus]. [žiūrèta 2013-19-13]. $<$ http://www.oecd.org/health/healthataglance/europe $>$.

3. European Community Pharmacy Blueprint. PGEU 2013 [interaktyvus]. [žiūrèta 201319-13]. <http://www.pgeu.eu/policy/19-the-european-community-pharmacy-blueprint. html>.

4. Lietuvos Respublikos farmacijos ịstatymas. Valstybės žinios. 2006, Nr. 78-3056.

17 PGEU Statement: Sustainable European Community Pharmacies Part of the Solution, 2013 [interaktyvus]. [žiūrèta 2013-19-13]. <http://www.pgeu.eu/en/press/80-european-pharmacists-call-on-european-governments-to-protect-the-sustainability-of-the-community-pharmacy-network.html $>$. 


\section{Pharmaceutical Care in the EU and Lithuania}

Jūratė Švarcaitè

Kaunas Medical University, Kaunas

\section{Summary}

Pharmaceutical care is the responsible provision of drug therapy for the purpose of achieving definite outcomes that improve a patient's quality of life. In Lithuania, pharmaceutical care will be implemented starting from 1st January, 2015, when a specific part of Good Pharmacy Practice reglamentation comes into force. Pharmaceutical care is implemented and well defined in many EU countries. Pharmaceutical care services are available to the patients and in many countries paid from the national health budget.

This article describes the concept of pharmaceutical care, looks into the role that pharmacists and community pharmacy play in primary care in different EU countries. Pharmaceutical care services are presented according to four main clusters of pharmacists' professional practice:

- Enhancing medicine safety and access to medicine, $\bullet$ Improving outcomes of individual patients,

- Improving public health,

- Contributing to health system efficiency.

According to experience of other EU member states, when implementing pharmaceutical care in Lithuania it is important to define the concept of pharmaceutical care, define standards, quality assurace system and accreditation.

Keywords: pharmaceutical care, community pharmacy, community pharmacist, primary care, European Union, pharmacy service.

Jūratė Švarcaitè, Master in Pharmacy, Kaunas Medical University, Master in Science, The School of Pharmacy, London University. Research interests: social pharmacy, public health policy, pharmacy practice, health systems.

Jūratė Švarcaitė, farmacijos magistras, Kauno Medicinos Universitetas; vaistininko praktikos magistras, Londono Farmacijos Mokykla, Londono Universitetas. Mokslinių tyrimų kryptys: socialinè farmacija, visuomenès sveikatos politika, farmacijos praktika, sveikatos sistema. 